\title{
The Effects Of Financial Education And Networks On Business Students' Financial Literacy
}

Yunhyung Chung, University of Idaho, USA Youngkyun Park, University of Idaho, USA

\begin{abstract}
This study investigates the joint effects of financial education and educational networks on students' financial literacy. With a sample $(N=105)$ of senior students in a business college, the study finds that not only financial education, but also strong networks with professors, are positively related to the financial literacy of business students. After controlling for financial education, the results reveal that students' educational network strength is positively associated with their financial literacy. On the contrary, students' personal networks are not significantly related to their financial literacy. This paper contributes to the literature on financial literacy by showing that individuals' financial networks with faculty, as well as financial education, can influence their financial literacy.
\end{abstract}

Keywords: Financial Literacy; Financial Networks; Financial Education

\section{INTRODUCTION}

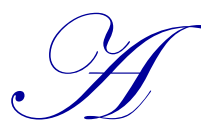

$\mathrm{s}$ economic and financial environments are complex and volatile, individual financial decisionmaking has been considered an important factor in determining individual well-being (Hung, Mihaly, \& Yoong, 2010). A large body of previous research has investigated what factors influence financial decision-making and suggested that individual financial knowledge and skills are critical for effective financial decisions. Extant research has found that financial literacy, defined as "the ability to use knowledge and skills to manage financial resources effectively for a lifetime of financial well-being" (U.S. Department of the Treasury, 2007), influences financial decision-making across many critical domains, including money management, credit, investment, and retirement planning. For instance, Perry and Morris (2005) show that financial literacy affects budgeting, saving, and spending. Moore (2003) and Campbell (2006) document that those with lower levels of financial literacy are more likely to have costly mortgages and not refinance them. Lusardi and Tufano (2009) show that those with low financial literacy are more likely to engage in high-cost borrowing. Those with low financial literacy are also less likely to participate in stock markets (van Rooij, Lusardi, \& Alessie, 2011) and less likely to plan for retirement (Lusardi \& Mitchell, 2008). Hence, it is important to understand what factors enhance financial literacy and thus may improve the quality of financial decision-making.

Past investigations of financial literacy and decision-making have been conducted in two different directions. On the one hand, they have highlighted financial education as a primary determinant of financial literacy and found that financial education effectively increases financial knowledge and consequently improves financial literacy (e.g., Lyons, 2005; Lyons, Palmer, Jayaratne, \& Scherpf, 2006). Another group of research has argued that financial education may not elevate financial literacy (e.g., Cole \& Shastry, 2008; Gale \& Levine, 2010; Willis, 2011) and highlighted the role of social interactions as predictors of financial literacy. The essence of the latter argument is that individuals can acquire financial knowledge through social interactions with financially literate ones, consequently enhancing their financial literacy (e.g., Duflo \& Saez, 2002; Brown, Ivković, Smith, \& Weisbenner, 2008; Kaustia \& Knüpfer, 2012). Although financial literacy and social interactions may be critical to improve financial literacy, the previous research has not examined them together. 
Taken these two streams of research together, this study intends to enhance understanding of college students' financial literacy. Because a level of financial literacy early in life would significantly affect their wealth accumulation, it would be important to understand what factors influence students' financial literacy (Lusardi, Michaud, \& Mitchell, 2011). Replicating the previous research, this study examines the relationship between financial education in colleges and business students' financial literacy. Using a social network analysis technique, however, the study explores the relationship between different types of social networks and business students' financial literacy.

\section{LITERATURE REVIEW AND HYPOTHESES}

Financial education has been identified as a primary determinant of financial literacy. Previous research found that company-provided financial education can effectively increase financial knowledge and consequently improve financial literacy (e.g., Lyons, 2005; Lyons, Palmer, Jayaratne, \& Scherpf, 2006). Corroborating these findings, research on college-level financial education has found that financial education in colleges improves investment knowledge more effectively than financial education in high schools (Peng, Bartholomae, Fox, \& Cravener, 2007). Financial education in colleges provides comprehensive and in-depth knowledge on finance and investment (Peng et al., 2007). In addition, because most college students who will soon be involved in financial decision-making (e.g., investments in a defined contribution plan), they are likely to be interested in financial education. In this regard, the following hypothesis is proposed:

Hypothesis 1: Financial education is positively related to students' financial literacy.

Although financial education improves one's financial literacy, a growing body of research continues to cast doubts on whether financial education can, in practice, effectively bring about behavioral change (e.g., Lyons, Chang, Scherpf, 2006; Cole \& Shastry, 2008; Gale \& Levine, 2010; Willis, 2011). This body of research proposes that financial literacy may be affected not only by financial education but also by social interactions (or networks) with the financially literate. Because individuals may acquire critical knowledge through their social ties (Chung \& Jackson, 2013), social networks may contribute to enhancing their financial literacy. Network ties can serve both instrumental/informational and expressive/social purposes (i.e., maintaining friendship) (Balkundi \& Harrison, 2006; Cascioaro \& Lobo, 2008). However, this study focuses on the instrumental role of networks, assuming that instrumental external ties are most relevant to acquiring financial knowledge and information.

If students interact with more people to acquire financial knowledge (i.e., a larger network size), they may have more chances to obtain a broader spectrum of information and knowledge (e.g., Chung \& Jackson, 2013; Gargiulo, Ertug, \& Galunic, 2009). In addition, frequent social interactions with people in the financial networks may help reduce a fixed cost of acquiring and processing information related to investment (Vissing-Jørgensen, 2003; Hong, Kubik, \& Stein, 2004). Social network research has suggested that strong relationships are useful for acquiring tacit and complex knowledge (Adler \& Kwon, 2002). Individuals are willing to share critical information only if they have close and strong interpersonal relationships with those in their financial networks (Hansen, Podolny, \& Pfeffer, 2001). Thus, close relationships with people in financial networks (i.e., a higher level of network strength) can improve students' financial literacy. Therefore, drawing on rich empirical and theoretical discussions on social interactions and networks in extant research, the following two hypotheses are proposed:

Hypothesis 2: Financial network size is positively related to students' financial literacy.

Hypothesis 3: Financial network strength is positively related to students' financial literacy.

In a college, students may have two types of financial networks - educational financial and personal financial. Students may establish networks with professors (entitled as "educational financial networks") and ones based on personal relationships with spouse/partner, parents, siblings, relatives, and friends (entitled as "personal financial networks"). The influence of the two types of networks on students' financial literacy may not be the same. Professors from whom students seek financial or investment information would likely be more financially literate, on average, than students' friends or family members. As a result, students are likely to acquire more complex knowledge on finance and investment from their educational financial networks than from personal financial networks. Therefore, the following hypothesis is proposed: 
Hypothesis 4: Students' financial literacy is more strongly associated with their educational financial network strength than personal financial network strength.

\section{METHODS AND MODEL SPECIFICATION}

\section{Sample and Procedure}

The authors surveyed 111 senior college students in a business school located in the northwestern United States. The surveys were conducted by using a traditional paper-and-pencil survey in the classroom in the Spring and Fall 2012 semesters. Students were told that the surveys were anonymous and that students who participated received class engagement credits. Six students who did not provide all the information were excluded from the sample, resulting in 105 respondents.

\section{Key Measures}

\section{Financial Literacy}

To measure students' financial literacy, this study first assumes that financial literacy can be captured by a level of financial knowledge or understanding following prior studies on financial literacy (e.g., Hilgert, Hogarth, \& Beverly, 2003; Lusardi \& Mitchell, 2007). Next, to evaluate students' financial knowledge, this study uses a battery of five questions from the National Financial Capability Study supported by the FINRA Investor Education Foundation. The five questions cover fundamental concepts of economics and finance, such as calculations about interest rates and inflation, the relationship between interest rates and bond prices, the relationship between interest payments and maturity in mortgages, and risk diversification. ${ }^{1}$ A higher score indicates a higher level of financial literacy.

\section{Financial Education}

Respondents' majors are used as a proxy for their financial education, assuming that financial education is taken more seriously when students major in economics, finance, or accounting than other areas (e.g., marketing or management). A dummy variable is used to indicate whether students major in at least one of the three areas.

\section{Financial Network Variables}

Following Chung and Jackson (2013) and Reinholt, Pedersen, and Foss (2011), an egocentric network technique is adopted to assess students' financial networks. Respondents list the first and last name initials of up to ten people, including spouse/partner, parents, siblings, relatives, friends, and professors, who they believe are most important resources for obtaining financial or investment information. Limiting the list of possible contacts to ten people may not allow respondents to describe their entire financial networks, but constraining the number of contacts listed has the benefit of making data collection more feasible (see Morrison, 2002).

Next, their financial networks are divided into educational financial and personal financial. Educational financial networks are defined as those tied with professors and personal financial networks as those tied with spouse/partner, parents, siblings, relatives or friends. Network size is defined as the total number of persons from whom a respondent acquires financial or investment information (Hansen et al., 2001). Thus, the size of educational financial networks indicates the total number of professors from whom a respondent acquires financial or investment information, and the size of personal financial networks indicates the total number of persons, other than professors, from whom a respondent acquires financial or investment information.

To measure the strength of respondents' financial networks, respondents were asked to answer the following question for each person in their networks: "During the five years, how often have you talked to each

\footnotetext{
${ }^{1}$ For the exact wording of the five questions, see the survey questions posted to the website of the National Financial Capability Study, http://www.usfinancialcapability.org/survey_data.html
} 
person in order to acquire financial and/or investment information?" $(0=$ Never, $1=$ Once a Year or Less, $2=$ Several Times a Year, $3=$ Once a Month, $4=2-3$ Times a Month, $5=$ Once a Week or More). Respondents' network strength refers to the average score of answers for persons in their networks. Therefore, the strength of educational financial networks indicates the average score of the relationship strength with professors, if any, in the network, while the strength of personal financial networks indicates the average score of the relationship strength with others except professors in the network. A higher score indicates a higher level of network strength.

\section{Model Specification}

To test the hypotheses on the relationships between educational financial networks and students' financial literacy, the following empirical model is estimated:

$F L_{i}=\beta_{0}+\beta_{1} F E_{i}+\beta_{2} E F N_{-}$Size $_{i}+\beta_{3} E F N_{-}$Strength $_{i}+\beta_{4} Z_{i}+\epsilon_{i}$.

Variable $F L_{i}$ indicates a student $i$ 's financial literacy measured by a score of the five questions covering fundamental concepts of economics and finance. As an independent variable, the model includes $F E_{i}$, which indicates a student $i$ 's financial education. It also includes $E F N_{-}$Size $_{i}$ and $E F N_{-}$Strength $_{i}$, which indicate a student $i$ 's educational financial network size and strength, respectively. $Z_{i}$ indicates a set of control variables.

\section{Control Variables}

Control variables include respondents' investment experience, grade point average (GPA), and demographic backgrounds. First, investment experience is controlled for because, when a respondent has any prior experience in investing, his/her financial literacy would differ than otherwise. Survey participants are asked to answer whether they have owned any stocks or mutual funds during the past five years $($ Yes $=1)$. When a respondent answers "Yes" in either stocks or mutual funds, he is regarded as one who has investment experience. Second, respondents' GPA is controlled for, as well as individual demographic characteristics such as gender (female $=1)$, age, and ethnicity (White $=1$, otherwise $=0$ ).

\section{RESULTS}

\section{Descriptive Statistics}

Table 1 presents descriptive statistics on the sample. The mean score of respondents' financial literacy is 4.14, which is greater than the 3.4 that Lusardi (2011) reported with a national survey sample of 1,488 adults in 2009 for college graduates or those with advanced degrees. The higher score may result from the fact that the sample consists of business students. The respondents in the sample have four or five people, on average, from whom they have obtained financial or investment information. Among the networks from which they seek financial information, one or two persons, on average, are linked to professors. The respondents have a higher level of network strength with professors than with personal connections. About 47 percent of the respondents have studied economics, finance, or accounting as a single or double major. About 38 percent of the respondents have investment experience. Female respondents consist of $36 \%$ of the sample. Respondents' age ranges from 20 to 35 with a mean age of 22.2. About $87 \%$ of the respondents are white.

Table 1 also reports correlation coefficients among respondents' financial literacy, financial education, and financial network variables. In the table, respondents' financial literacy is significantly positively related to their educational financial network size and strength. 
Table 1: Sample Descriptive Statistics and Correlations

\begin{tabular}{|c|c|c|c|c|c|c|c|c|c|}
\hline & mean & s.d. & 1 & 2 & 3 & 4 & 5 & 6 & 7 \\
\hline 1. Financial literacy & 4.14 & 0.80 & 1.00 & & & & & & \\
\hline 2. Financial education & 0.47 & 0.50 & $0.41 * * *$ & 1.00 & & & & & \\
\hline $\begin{array}{l}\text { 3. Total financial network } \\
\text { size }\end{array}$ & 4.54 & 2.39 & -0.01 & 0.01 & 1.00 & & & & \\
\hline $\begin{array}{l}\text { 4. Educational financial } \\
\text { network size }\end{array}$ & 1.64 & 0.83 & $0.23 * *$ & $0.33 * * *$ & $0.22 * *$ & 1.00 & & & \\
\hline $\begin{array}{l}\text { 5. Personal financial } \\
\text { network size }\end{array}$ & 4.11 & 2.34 & -0.09 & -0.10 & $0.94 * * *$ & -0.12 & 1.00 & & \\
\hline $\begin{array}{l}\text { 6. Educational financial } \\
\text { network strength }\end{array}$ & 3.66 & 1.72 & $0.30 * * *$ & $0.34 * * *$ & 0.14 & $0.83 * * *$ & -0.14 & 1.00 & \\
\hline $\begin{array}{l}\text { 7. Personal financial } \\
\text { network strength }\end{array}$ & 3.19 & 1.04 & 0.03 & 0.07 & -0.13 & 0.08 & -0.16 & $0.21 * *$ & 1.00 \\
\hline
\end{tabular}

\section{Effects of Financial Education on Financial Literacy}

Table 2 presents regression results with different settings of the model described in the previous section. In order to avoid the potential multicollinearity problem in the model, different settings for the financial network variables are employed. Regardless of different settings, financial education is significantly positively related to students' financial literacy. Thus, the results indicate that students' financial literacy is positively affected by financial education, supporting Hypothesis 1.

Table 2: Regression Results: Business Students' Financial Literacy

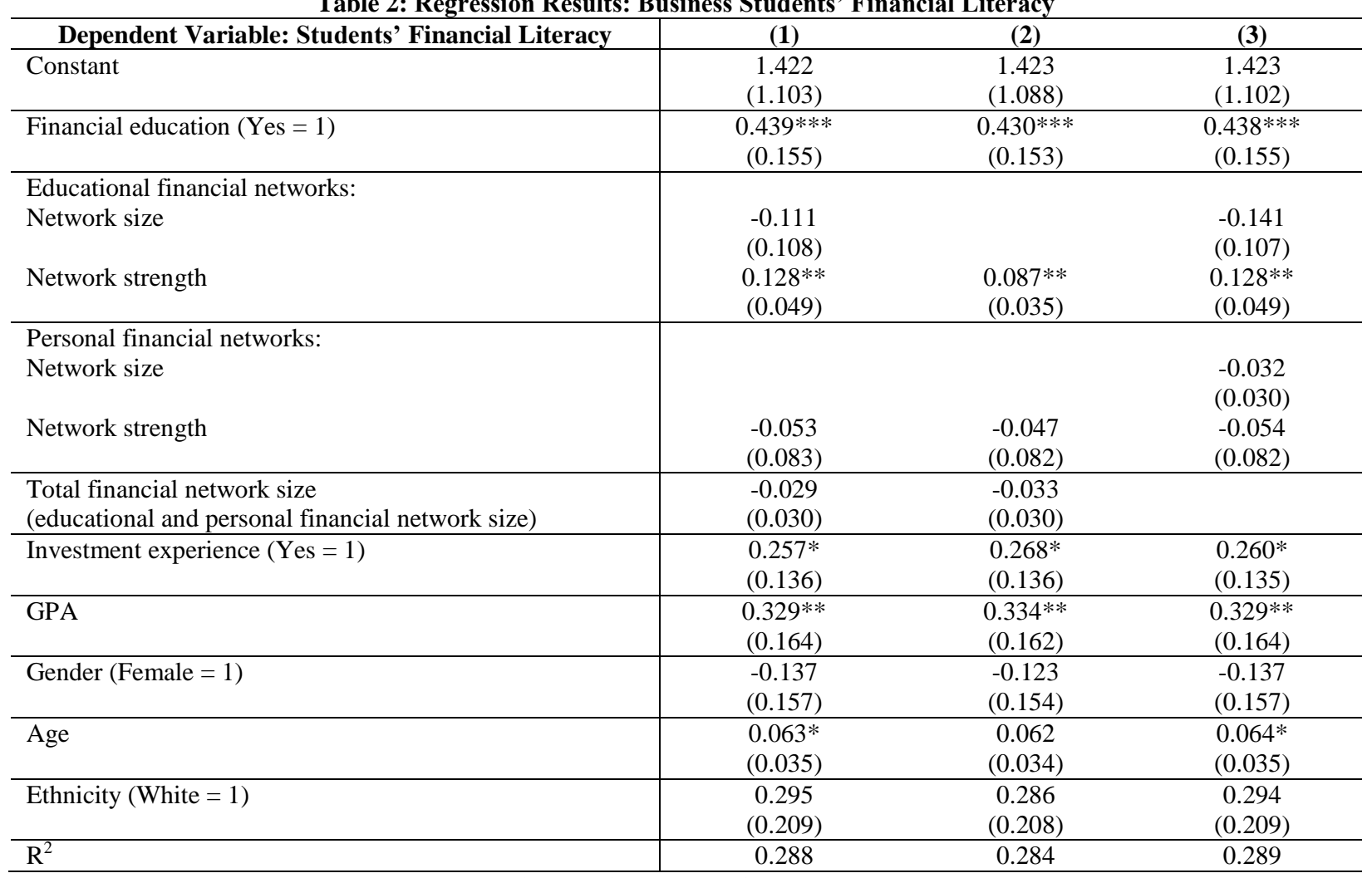

Note: $\mathrm{N}=105, * * * \mathrm{p}<0.01, * * \mathrm{p}<0.05, * \mathrm{p}<0.1$. Robust standard errors are in parentheses. 


\section{Effects of Educational Financial Networks on Financial Literacy}

The results presented in the table consistently show that respondents' educational and personal financial network size is not significantly related to their financial literacy, which does not support Hypothesis 2. However, their education financial network strength is significantly positively related to their financial literacy while personal financial network strength is not. Therefore, Hypotheses 3 and 4 are partially supported. In particular, the positive effects of educational financial network strength on students' financial literacy are consistent across the different settings. First, results in Column 1 indicate that when a respondent's network strength with professors increases from "once a month" to "2-3 times a month," his/her financial literacy increases by $12.8 \%$ after controlling for other variables. Second, when educational financial network size is dropped from the model because of its potential collinearity with educational financial network strength, the effect of the network strength with professors is still significant, even though its magnitude is reduced by $32 \%$ (see Column 2). Last, when personal financial network size, instead of the total financial network size, is included in the model (Column 3), the effect of respondents' network strength with professors on his/her financial literacy is restored to a level of $12.8 \%$. Thus, the results presented in Columns 1-3 show that a respondent's financial literacy can be increased by $8.7-12.8 \%$ when he/she contacts professors more frequently for the purpose of getting financial or investment information. The increase in respondents' financial literacy is obtained when their majors and investment experience are controlled for.

In contrast to educational financial networks, personal financial networks are not significantly related to students' financial literacy. The different effects of educational and personal financial networks may be related to a level of financial literacy of the persons in the network. Professors would more likely be financially literate than spouse/partner, parents, siblings, relatives, or friends. Thus, it can be inferred that when a student meets people having a high level of financial literacy more frequently, his/her financial literacy is more likely to increase.

\section{CONCLUSION}

This study examines whether financial networks, as well as financial education, affect students' financial literacy. With a complete sample of 105 senior business college students, the study finds first that financial education is positively related to students' financial literacy as the literature on financial education documents. Second, it finds that, when students have strong networks with professors, they are likely to be more financially literate. The findings suggest that in order to improve students' financial literacy, formal financial education may not be enough; more interactions with faculty would contribute to enhancing students' financial literacy. Therefore, providing students more opportunities to interact with faculty, such as participating in experiential learning programs (e.g., investment clubs), may increase the likelihood of improving students' financial literacy.

\section{AUTHOR INFORMATION}

Yunhyung Chung, Ph.D., Assistant Professor of Management and Human Resources, College of Business and Economics, University of Idaho, 875 Perimeter Drive MS 3161, Moscow, ID 83844-3161, USA. E-mail: yunchung@uidaho.edu

Youngkyun Park, Ph.D., Assistant Professor of Finance, College of Business and Economics, University of Idaho, 875 Perimeter Drive MS 3161, Moscow, ID 83844-3161, USA. E-mail: youngpark@uidaho.edu (Corresponding author)

\section{REFERENCES}

1. Adler, P. S., \& Kwon, S. W. (2002). Social capital: Prospects for a new concept. Academy of Management Review, 27, 17-40.

2. Balkundi, P., \& Harrison, D. A. (2006). Ties, leaders, and time in teams: Strong inference about network structure's effects on team viability and performance. Academy of Management Journal, 49, 49-68.

3. Brown, J. R., Ivković, Z., Smith, P. A., \& Weisbenner, S. J. (2008). Neighbors matter: Causal community effects and stock market participation. Journal of Finance, 63, 1509-1531.

4. Campbell, J. (2006). Household finance. Journal of Finance, 61(4), 1553-1604. 
5. Cascioaro, T., \& Lobo, M. S. (2008). When competence is irrelevant: The role in interpersonal affect in task-related ties. Administrative Science Quarterly, 53, 655-684.

6. Chung, Y., \& Jackson, S. E. (2013). The internal and external networks of knowledge-intensive teams: The role of task routineness. Journal of Management, 39, 442-468.

7. Cole, S., \& Shastry, G. K. (2008). If you are so smart, why aren't you rich? The effects of cognitive ability, education, and financial literacy on financial market participation. Paper presented at 2009 Federal Reserve System Community Affairs Research Conference, Washington, D.C.

8. Duflo, E., \& Saez, E. (2002). Participation and investment decisions in a retirement plan: The influence of colleagues' choices. Journal of Public Economics, 85, 121-148.

9. Gale, W. G., \& Levine, R. (2010). Financial literacy: What works? How could it be more effective? Paper presented at the First Annual Conference of the Financial Literacy Research Consortium, Washington, D.C.

10. Gargiulo, M., Ertug, G., \& Galunic, C. (2009). The two faces of control: Network closure and individual performance among knowledge workers. Administrative Science Quarterly, 54, 299-333.

11. Hansen, M., Podolny, J. M., \& Pfeffer, J. (2001). So many ties, so little time: A task contingency perspective on the value of social capital in organisations. In: S. M. Gabbay \& R. Th. A. J. Leenders (Eds.), Research in the sociology of organizations (Vol. 18, pp. 21-57). London: Jai Press.

12. Hilgert, M. A., Hogarth, J. M., \& Beverly, S. G. (2003). Household financial management: The connection between knowledge and behavior. Federal Reserve Bulletin, 7, 309-322.

13. Hong, H., Kubik, J. D., \& Stein, J. C. (2004). Social interaction and stock-market participation. Journal of Finance, 59, 137-163.

14. Hung, A. A., Mihaly, M., \& Yoong, J. K. (2009). Federal financial and economic literacy education programs, 2009. RAND Corporation.

15. Kaustia, M., \& Knüpfer, S. (2012). Peer performance and stock market entry. Journal of Financial Economics, 104, 321-338.

16. Lusardi, A. (2011). Americans' financial capability. (Pension Research Council Working Paper, PRC WP2011-02).

17. Lusardi, A., \& Mitchell, O. S. (2007). Financial literacy and retirement planning: New evidence from the Rand American life panel. (Michigan Retirement Research Center Working Paper, WP2007-157).

18. Lusardi, A., \& Mitchell, O. S. (2008). Planning and financial literacy: How do women fare? American Economic Review: Papers and Proceedings, 98(2), 413-417.

19. Lusardi, A., \& Tufano, P. (2009). Debt literacy, financial experiences, and overindebtedness. (NBER Working Paper 14808). Cambridge, Mass.: National Bureau of Economic Research.

20. Lusardi, A., Michaud, P.-C., \& Mitchell, O. S. (2011). Optimal financial literacy and saving for retirement. (Pension Research Council Working Paper, PRC WP2011-20).

21. Lyons, A. C. (2005). Financial education and program evaluation: Challenges and potentials for financial professionals. Journal of Personal Finance, 4(4), 56-68.

22. Lyons, A. C., Chang, Y., \& Scherpf, E. (2006). Translating financial education into behavior change for low-income populations. Journal of Consumer Affairs, 40(20), 208-235.

23. Lyons, A. C., Palmer, L., Jayaratne, K. S. U., \& Scherpf, E. (2006). Are we making the grade? A national overview of financial education and program evaluation. Journal of Consumer Affairs, 40(20), 208-235.

24. Moore, D. (2003). Survey of financial literacy in Washington State: Knowledge, behavior, attitudes, and experiences. (Technical Report 03-39). Pullman, Wash.: Washington State University Social and Economic Sciences Research Center.

25. Morrison, E. W. (2002). Newcomers' relationship: The role of social network ties during socialization. Academy of Management Journal, 45, 1149-1160.

26. Peng, T., Bartholomae, S., Fox, J., \& Cravener, G. (2007). The impact of personal finance education delivered in high school and college courses. Financial Counseling and Planning, 17(2), 27-45.

27. Perry, V. G., \& Morris, M. D. (2005). Who is in control? The role of self-perception, knowledge, and income in explaining consumer financial behavior. Journal of Consumer Affairs, 39(2), 299-313.

28. Reinholt, M., Pedersen, T., \& Foss, N. J. (2011). Why a central network position isn't enough: The role of motivation and ability for knowledge sharing in employee networks. Academy of Management Journal, 54, 1277-1297.

29. U.S. Department of the Treasury. (2007). Strategy for assuring financial empowerment. Washington, D.C. 
30. Van Rooij, Lusardi, M. A., \& Alessie, R. (2011). Financial literacy and stock market participation. Journal of Financial Economics, 101, 449-472.

31. Vissing-Jørgensen, A. (2003). Perspectives on behavioral finance: Does “irrationality” disappear with wealth? Evidence from expectations and actions. National Bureau of Economic Research Macroeconomics Annual (pp. 139-208).

32. Willis, L. E. (2011). The financial education fallacy. American Economic Review: Papers and Proceedings, 101(3), 429-434. 